\title{
Caracterização de vinagre de fruta - maçã, a partir de frutos de cultivo orgânico e convencional.
}

\author{
Fernanda Silva Farinazzo ${ }^{1}$, Sandra Garcia ${ }^{1}$, Wilma Aparecida Spinosa ${ }^{1}$ \\ Universidade Estadual de Londrina - Departamento de Ciência e Tecnologia de Alimentos \\ Caixa postal 10.011 - 86057-970 - Londrina - Pr - wilma.spinosa@uel.br
}

Introdução: Vinagre de fruta - maçã é o produto da categoria mais conhecido e consumido no Brasil, e apresenta variedade de ácidos orgânicos, vitaminas, minerais, compostos fenólicos e outros elementos importantes nas funções fisiológicas, nutricionais e sensoriais. Os componentes encontrados na maçã e por consequência no vinagre proveniente do fruto, podem apresentar diferentes composições químicas, dependendo da forma de cultivo ser orgânico ou convencional. $\mathrm{O}$ trabalho objetivou comparar as características dos vinagres de maçã, produzidos por fermentação acética, a partir do vinho de maçã, do fruto cultivado pelos sistemas orgânico e convencional. Métodos: 0 processo de fermentação, com cultura mista, foi o conhecido como rápido ou alemão, à temperatura de $30^{\circ} \mathrm{C}$. Os parâmetros avaliados no produto final foram (a) acidez total; (b) acidez volátil; (c) pH; (d) extrato seco; (e) minerais; (f) cinzas; ( $g$ ) fenólicos totais, (h) capacidade antioxidante e (i) lisina. Utilizouse a espectrofotometria de absorção atômica (Perkin-Elmer ${ }^{\odot}$ 2380, USA) com gás de chama ar-acetileno, para quantificar os teores de cálcio, sódio, potássio e cloreto e espectrofotometria de UV-VIS para determinar lisina. Fenólicos totais foram quantificados pela reação com reagente de Folin-Ciocalteau e capacidade antioxidante em relação ao sequestro do radical 2,2-difenil-1-picril-hidrazil (DPPH). As amostras foram provenientes de uma indústria localizada na cidade de Assis (SP). Resultados: Os vinagres de maçã, ambos com acidez total (a) de $4,1 \%(\mathrm{~m} / \mathrm{v})$, orgânico e convencional apresentaram respectivamente: (b) acidez volátil 1,45 e 1,38\% (m/v); (c) pH 2,68 e 2,94; (d) extrato seco 7,77 e 4,57 g/L; (f) cinzas 12,5 e 6,2 g/L; (g) fenólicos totais 293,897 e 109,632 $\mu \mathrm{g}$ de GAE/ mL de vinagre, (h) capacidade antioxidante 16,7 e 7,53\% de sequestro do radical DPPH e (i) lisina 69,83 e $76,63 \mathrm{mg} / \mathrm{L}$. Os mineras (e) com diferença significativa $(p<0.05)$ foram cloretos $(1829,22$ e $1595,25 \mathrm{mg} / \mathrm{L})$, potássio $(660$ e $575,12 \mathrm{mg} / \mathrm{L})$ e cálcio $(616,7$ e $862,0 \mathrm{mg} / \mathrm{L})$. Conclusão: A partir dos resultados obtidos pode se inferir que os vinagres com mesmo teor de acidez apresentaram diferença quantitativa nos compostos químicos avaliados.

Palavras-chave: Malus domestica, antioxidantes, minerais, fermentado acético

Universidade Estadual de Londrina - Rodovia Celso Garcia Cid, Pr 445, Km 380 - Campus Universitário Caixa Postal 10.011 CEP 86057-970 Centro de Ciências Exatas - Departamento de Bioquímica e Biotecnologia Fone +55 (43)3371.4270 - biq@uel.br 